\title{
Development of the system for gene therapy of AIDS on the basis of antisense RNAs
}

\author{
A. D. Shved, O. P. Kukharenko \\ Institute of Molecular Biology and Genetics, NAS of Ukraine \\ 150, Akademika Zabolotnogo Str., Kyiv, Ukraine 03680 \\ adshved@email.ua
}

\begin{abstract}
Based on adeno-associated virus derived plasmid construct that are able to synthesize in cells antisense RNAs directed against key genes of HIV. Gematopoietic human cells carrying the created structure, acquired resistance to HIV infection, as evidenced by the reduction in infectious titer of HIV in cell culture. The resulting system of intracellular resistance to retrovirus can be seen as a model of gene therapy of AIDS.
\end{abstract}

Keywords: HIV-AIDS, adeno-associated virus, antisense RNAs, gene therapy, gematopoietic human cells.

The development of the methods of sequencing and artificial synthesis of nucleic acids, the discovery of the enzymes of restriction and reverse transcription, the elaboration of the technology of polymerase chain reaction as well as the discovery of the natural mechanism of antisense regulation of gene expression played a critical role in the radical changes in the possibilities of molecular biology to solve the most urgent problem of the life sciences - targeted regulation of gene expression. Scientific and practical facilities in solving this problem have become goal-oriented and developed in two directions: artificial synthesis of antisense oligonucleotides and the development of systems of intracellular biosynthesis of antisense RNA-transcripts, complementary to specific mRNA sites of the selected target gene. Due to the discovery of catalytic properties, remarkable for a specific class of RNA molecules, called ribozymes, we witnessed the formation of a new branch of the latter trend - the elaboration of molecular constructions for intracellular synthesis of ribozymes, capable of cutting RNA-transcripts, against which they were directed. Extremely high specificity of the ribozymes activity, conditioned by the sequence of as few as several nucleotides, provided the researchers with another effici-

(c) Institute of Molecular Biology and Genetics, NAS of Ukraine, 2013 ent instrument of regulating the expression of harmful or undesired genes. Taking into account the possibilities and promising results of new approaches to the regulation of gene expression, numerous scientists, searching for the ways to control viral infections, turned to the methods of creating intracellular antiviral immunity using antisense RNA (asRNA) and ribozymes. We have contributed our efforts thereto, working in the framework of the program of the National AIDS Prevention Committee.

The common strategy, developed during several years of using asRNA to inhibit the reproduction of viruses, foresaw some general rules of selecting the target gene within the whole viral genome $[1,2]$. Both the theory and experience proved that in the majority of cases the efficiency of asRNA in blocking a corresponding mRNA depends on their molar ratio in the cell during the time of their expression $[2,3]$. Thus, the target in the cell has to be low-tracing, to have the possibility of creating the excess of antisense transcripts compared to coding viral mRNA. Therefore, it is reasonable to direct asRNAs to early viral genes, coding for the regulatory factors, mRNA-copying ability of which is insignificant. It provides better chances to acquire the excess of asRNA and to affect the kinetics of its interaction with a target mRNA for the benefit of forming a sense-antisense hybrid. 


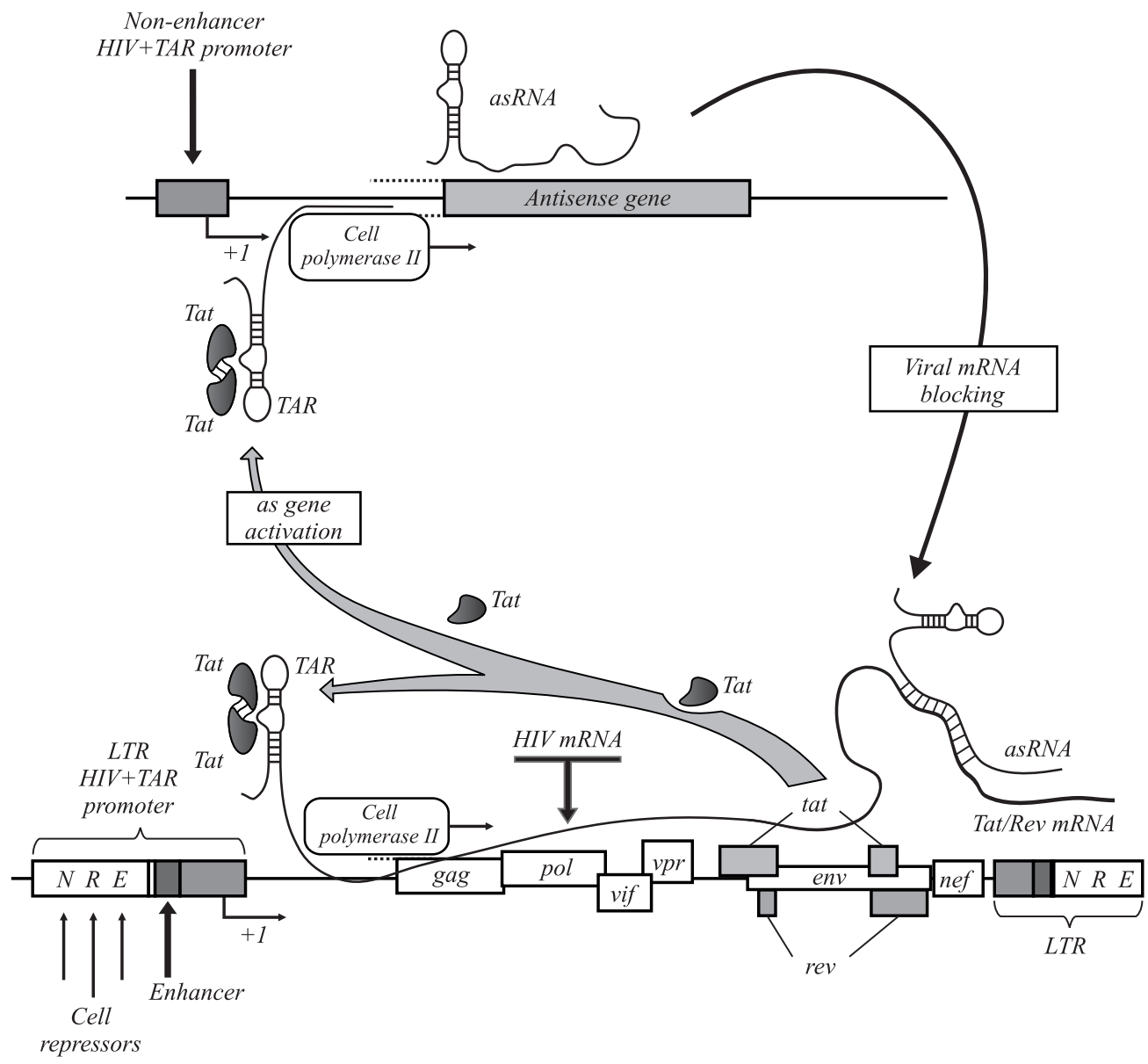

Fig. 1. The scheme of intracellular regulation of transcription of antisense RNA against Tat/Rev mRNA HIV-1 and the mechanism of negative feedback from regulatory genes of the virus. Upper part - antisense gene; bottom - genome of HIV-1 provirus [4]
The computerized analysis of published sequences of many HIV-1 isolates allowed selecting another area Tat-Rev exon with flanks, where the reading frames of early regulatory and late structural viral proteins overlap - as a target for antisense effect. The defined region of HIV-genome encodes the regulatory proteins, vital for productive virus infection and key genetic signals, and is conservative for the majority of HIV-1 isolates.

The next step in constructing a gene of asRNA was the selection of the promoter to direct its synthesis in the cell. It was decided that it would be reasonable to implement the principle of reverse connection between the antisense gene and HIV-1 genome for the expression of antiviral antisense transcripts. It is possible if the synthesis of asRNA is directed by HIV promoter, activated by early products of HIV-genome, namely, transactivator Tat. In this case the level of asRNAs expression would depend on the expression of the most important HIV-1 genes (Fig. 1), i. e. the cell should have the state of balanced counteraction, where asRNAs control the level of key viral products at the pre-threshold level and thus block the transition of the viral infection into the productive phase. This principle of applying the transcriptional system of HIV promoter was successfully used by other laboratories [4] for intracellular expression of some genes with anti-HIV activity or super expression of different recombinant genes with non-specific antiviral activity (interferons, etc.). Pursuant to the determined properties there was a designed non-enhancer HIV promoter with triple tandem of $S P$ - 1 elements of transcriptional factors and $T A R$-element for the interaction with HIV-transactivator Tat. In a non-transformed cell this promoter is stronger than the native one, as it is not a subject to the effect of negative cellular factors. The sequence of the created recombinant promoter demonstrated the correspondence to the transcriptional HIV unit 


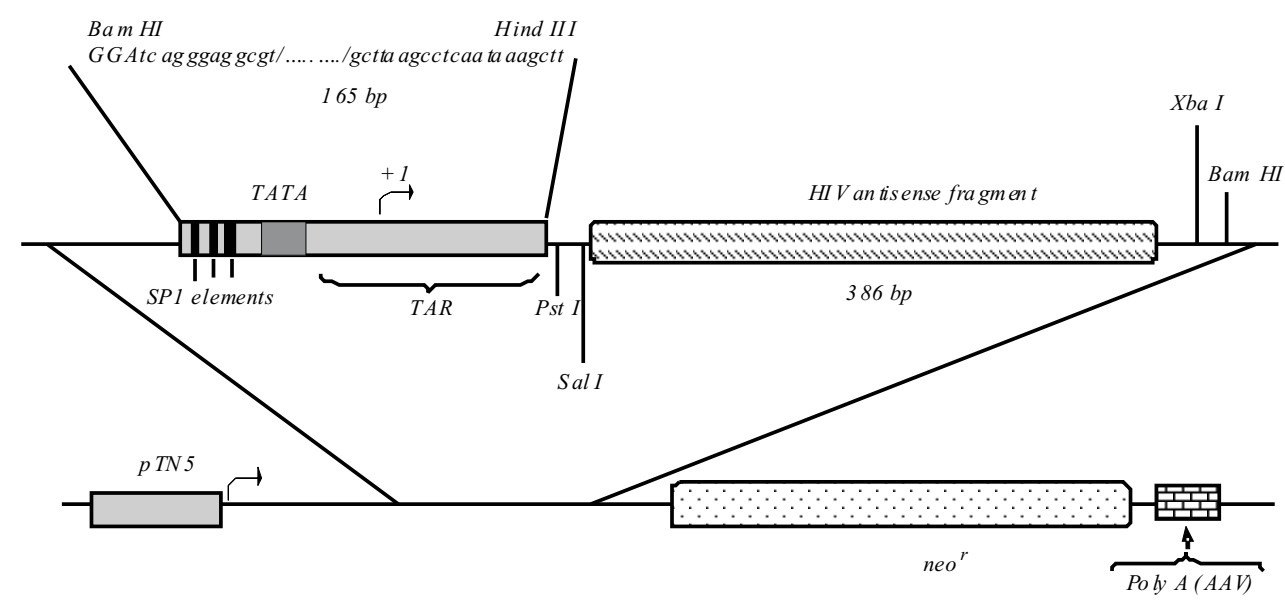

Fig. 2. Transcriptional unit of the created antisense gene: 165-nucleotide fragment enhancer-free promoter LTR HIV-1 with binding sites for transcriptional factors SP-I, TATA-box and TAR-element of HIV promoter; + 1 - start of transcription; 386-nucleotide fragment - sequence of HIV genome, cloned in antisense orientation relative to $\mathrm{HIV}$ promoter [4] with TATA-initiator, the main elements of transcription initiation $S P-1$ - and TAR-element (Fig. 2).

The vector, selected by us, was human adeno-associated virus (AAV), the advantages of which were highlighted in a number of publications $[5,6]$. Besides, the

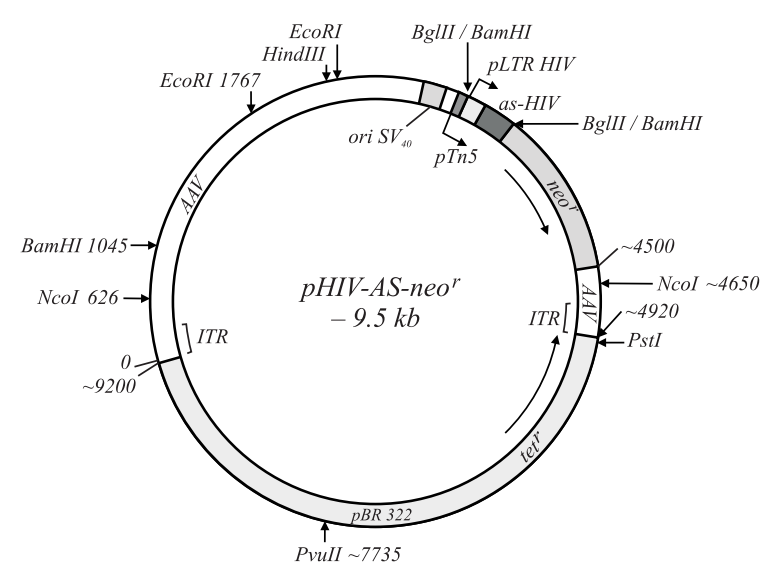

Fig. 3. The scheme of vector $p H I V$-as-neo, expressing anti-HIV asRNA

projective vector should contain a selective marker for transfected cells. This selected vector was a traditionally used resistance gene to aminoglycoside antibiotics $n e o^{\mathrm{r}}$, which allows selecting transfected cells in the medium with antibiotic G418. The own AAV transcription terminator of viral vector was used to terminate the transcription of asRNA.

The created antisense construction $p H I V$-as-neo is presented in Fig. 3. The basis of the molecular vector is AAV genome without genes of structural proteins, which is cloned into the gene $a m p^{\mathrm{r}}$ of plasmid $p B R 322$.
The place of genes of structural proteins in AAV-vector is taken by the cloned selective gene of neomycin phosphotransferase $n e o^{\mathrm{r}}$ and HIV-antisense gene. During the transfection of this plasmid into cells the DNA sequence, flanked by terminal repeats (ITR AAV), should be stably integrated into the chromosome of human hematopoietic cells. The transcription of asRNA from this recombinant construction is provided by the cloned and enhancer-free HIV-1 promoter.

The sequence of the cloned fragment demonstrated that it corresponds to the transcriptional HIV unit with TATA-initiator, the main elements of $S P-1$ transcription initiation and TAR-element, the efficiency of which can be enhanced by the protein Tat via TAR-element. In this construction the constitutive expression is enhanced by the promoter Tn5, located above. Therefore, asRNA is synthesized as a constituent of mRNA of gene neo in its 5'-non-coding part. Besides the antisense mechanism of inhibiting HIV replication, ensuring the created antisense gene, there is an expectation of the additional impact on HIV from Rep-protein of AAV, which has already been reported in scientific literature [7-10], and from TAR-element, also mentioned in the literature as an executive link of the mechanism of HIV replication block, called TAR-decoy $[11,12]$.

The study on the sensitivity of intact hematopoietic cells of human embryo liver to HIV-infection demonstrated that only in two (samples 7 and 10) out of 25 investigated samples of cells, isolated from different embryos, the synthesis of antigen p24 (Fig. 4, $A$ ) and the titers of the infectious virus (Fig. 4, $B$ ) were compatible to these indices of viral reproduction in the standard 

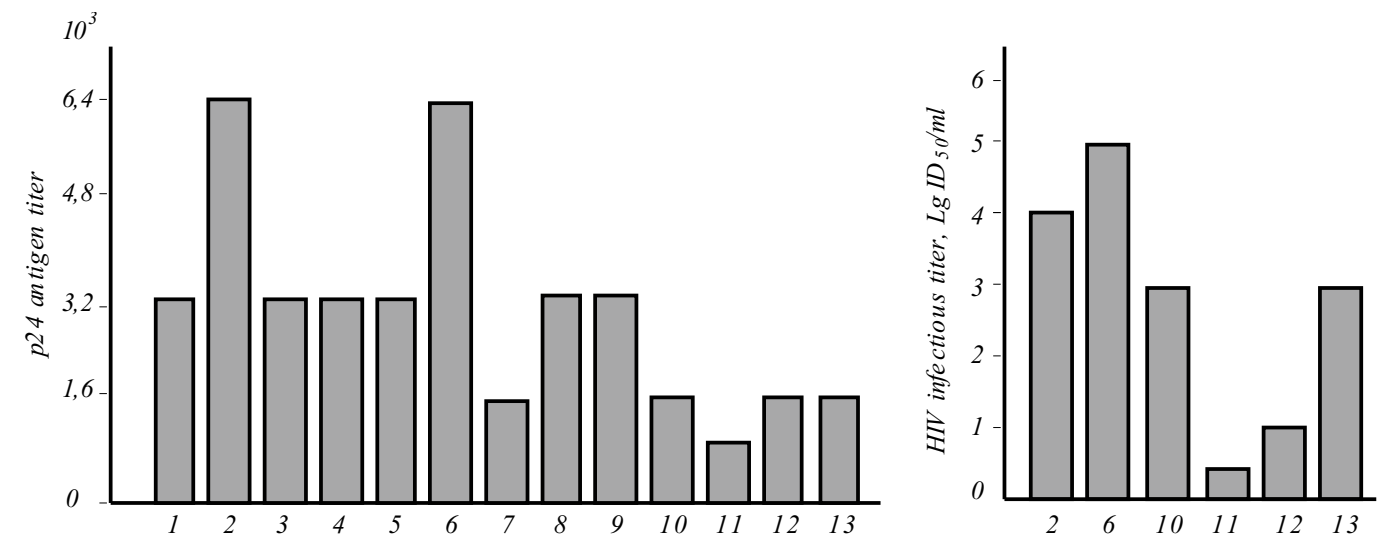

Fig. 4. HIV-1 reproduction in hematopoietic cells of human embryo liver: 1-12numbers of cultures from different embryos; 13 - cells of MT-4 line. Typical data are presented for illustration

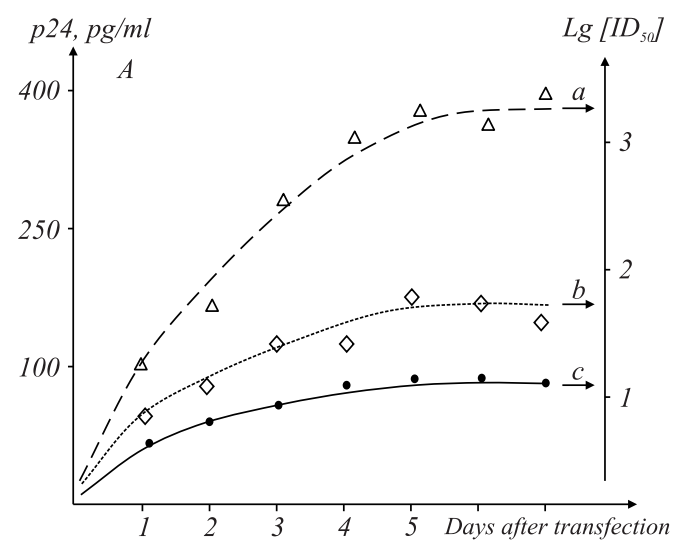

p24, pg/ml

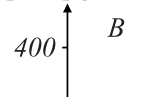

$\operatorname{Lg}\left[I D_{s a}\right]$ [14]

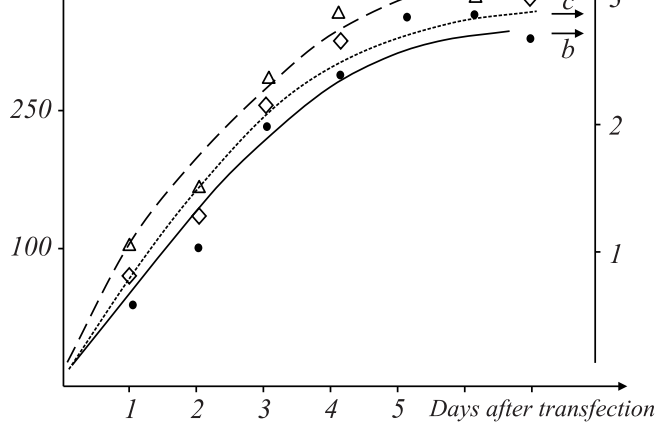

Fig. 5. The effect of antisense vector construction on HIV reproduction in hematopoietic cells: $A-$ in the presence of antibiotic G-418; $B-$ without the antibiotic ( $a$ - non-transfected cells; $b$ cells, transfected with vector construction $p D L 52$ 91neo; $c$ - cells, transfected with antisense vector construction $p H I V$-as-neo) [4]

cell culture MT-4, traditionally used in the experiments of HIV isolation and titration. In our studies the infectious titer of the virus in sample 12 was lower than the rest, while no virus presence was detected in sample 11, which testifies to either considerable or complete resistance of these cells to HIV-infection. Infectious indices were rather high in the cultures of cells from the rest of embryo samples - sometimes exceeding by $2 \lg \mathrm{ID}_{50}$ the HIV titer in cells MT-4 (Fig. 4, $B$, samples 2 and 6 ).

Numerous references demonstrate that along with typical tempo of HIV-infection progress some patients had a rapid transition to AIDS stage, for others this process was very slow, and a small percentage stayed healthy, regardless of previous, often repeated, infection incidents. Different indices of HIV-resistance for different samples of hematopoietic cells, revealed in our experiments, are somewhat similar to the distribution of clinical infection rates, although one should not expect their absolute coincidence as our experiment in vitro lacked the components of immune protection of the macroorganism. However, one can state that the data, obtained on the cellular level, were indirect testimony to the existence of natural mechanisms of resistance to HIV-infection.

The data of virologic studies are presented in Fig. 5. In the chosen cultivation conditions (with antibiotic G418) the cells, transfected with vector plasmid pDL5291neo, having the sequences of Rep-protein AAV without the antisense fragment, demonstrated the inhibition of HIV reproduction by $15-25 \%$. The effect of inhibiting virus replication in this experiment (virus control) may be conditioned by the activity of Rep-protein AAV. There was no significant impact on HIV-infection in the control experiment, where the cells were transfected with the plasmid, containing only terminal repeats of AAV (i. e. incapable of synthesizing Rep-protein AAV). This is indirect evidence to the data of [710] on the capability of AAV-specific Rep-protein to inhibit HIV reproduction.

The reduction in antigen production by $66 \%$ and the infectious titer of HIV by $99 \%$, compared to the cultures without antisense constructions, was observed while determining the virus titer and its production of antigen p24 in the population of cells, transfected with antisen- 
se plasmid and cultivated in the presence of selective antibiotic. The reduction in the infectious titer of the virus (by two orders) is a decisive index of inhibitory effect, but the synthesis rate of virus-specific protein p24 in our experiments could be estimated with less optimism. However, the analysis of data obtained testifies to the absence of gross mistakes both in the establishment of genetic constructions and in their testing. The arguments for the latter statement can be explained as follows.

The most decisive result in favor of anti-HIV efficiency of the created antisense construction is the index of significant reduction of the titer of the infectious virus in the cells, transfected by it. The antisense RNA transcripts in the elaborated system are directed towards the inhibition of the expression of regulatory Tat and Rev-proteins of HIV, which, as stated above, are critical constituents of the virus replication cycle.

The traditional and common method of detecting viral infection by the level of protein p24 synthesis during the testing of our construction is not sufficient to reflect the actual picture of infectious process, as it does not relate to the biosynthesis mechanism of this protein directly. Protein p24 is the product of gene gag; it is a structural group-specific protein, building the envelope of HIV nucleoid, synthesized in large quantities.

The realization of functions of our construction occurs in response to HIV appearing in the cell, its early product - protein Tat, in particular. This protein activates the transcription of the viral genome, which results in the launch of synthesis of other viral proteins, including the products of gene gag. The transcription of HIV genome stops with accumulating antisense RNA in the cell, but the synthesis of p24 goes on RNA-transcripts, which occurred in the initial period of viral infection until their complete degradation. As the assembly of virions takes place at the later stages of the infectious process and depends on the presence of all the structural components, the synthesis of which depends on free functioning of regulatory mechanisms, the latter are damaged by antisense effect and it impacts the formation of infectious viral particles.

In our opinion, this progress is reflected by our data: the indices of the yield of mature (infectious) HIV in the cells, transfected by antisense construction, were determined in smaller amounts than the indices of the content of virus-specific antigen p24.
It should be mentioned that in case of cultivation without any selective pressure the there was not registered significant inhibition of virus reproduction in the cells, transfected by both antisense plasmid and control vector plasmids (Fig. 5, c). It is conditioned by the fact that only 3-5\% of populations of infected cells are ensured by the antisense intracellular immunity. The major part of population cells is not transfected and in the absence of anti-metabolite, aminoglycoside antibiotic, they preserve the normal level of viability and normal sensitivity to HIV-infection. In the conditions of selective pressure of G418 some cells perish, metabolism is inhibited, so, these conditions are either hardly suitable for the support of viral reproductive cycle or this process is completely impossible.

Taking into consideration the achieved positive results of inhibiting in vitro replication of HIV in human hematopoietic cells with antisense vector constructions, one might assume that once these cells are transfused to the patient with AIDS, they will take on the functions of immune protection of the organism. One could also assume that once the blood flow is filled with HIV-resistant descendants of transplanted stem hematopoietic cells and predecessor cells, the blood of the HIV-infected recipient would gradually clear from the agent.

Taking into account the presence of viral protein p24 in transfected cells and some others, as well as a trace level of the formation of mature virions, one might expect that during this controlled infectious process the organism will produce antiviral antibodies, which will promote the formation of immune protection. If the assumed effects take place in the patient's organism, it could be possible that transplantation of HIV-resistant hematopoietic cells will prolong his life or at least alleviate his suffering. The results of clinical trials of our system for gene therapy of AIDS could confirm (or demolish) the abovementioned assumptions.

Therefore, our investigations resulted in the elaboration of the gene therapy system for AIDS, which is composed of human hematopoietic cells, protected from HIV by intracellular immunity. This immunity is based on the molecular genetic construction, built using AAV-vector, containing an LTR-derivative HIV-transcriptional unit, capable of induced synthesis of asRNA, directed against key HIV genes - tat and rev. The induction of synthesis of antisense transcripts is perfor- 
med by HIV-specific proteins in the early period after the intervention of the agent into the cell. Our antisense system can be used for further pre-clinical trials.

The results, obtained while conducting the investigations, were used in $\mathrm{PhD}$ and doctorate theses, highlighted in 6 publications and presented at 3 scientific forums.

\section{А. Д. Швед, О. П. Кухаренко}

Створення системи генної терапії СНІДу

на основі антисенсових РНК

Резюме

На базі аденоасоиійованого вірусу отримано плазмідну конструкиію, здатну до синтезу в клітині антисенсових РНК, спрямованих проти ключових генів ВІЛ. Гемопоетичні клітині людини, що несуть в собі створену конструкиію, набувають стійкості до ВІЛ-інфекиії, що засвідчує зниження інфекиійного титру ВІЛ у культурі клітин. Одержану систему внутрішньоклітинної резистентності до ретровірусу можна розглядати як модель генотерапї СНІДу.

Ключові слова: ВІЛ-СНІД, аденоасоиійований вірус, антисенсові РНК, генна терапія, гемопоетичні клітині людини.

\section{А. Д. Швед, А. П. Кухаренко}

Создание системы генной терапии СПИДа на основе антисмысловых РНК

Резюме

На базе аденоассоциированного вируса получена плазмидная конструкиия, способная синтезировать в клетке антисмысловые РНК, направленные против ключевых генов ВИЧ. Гемопоетические клетки человека, несущие созданную конструкиию, приобретают устойчивость к ВИЧ-инфекиии, о чем свидетельствует снижение инфекционного титра ВИЧ в культуре клеток. Полученную систему внутриклеточной резистентности к ретровирусу можна рассматривать как модель генотерапии СПИДа.

Ключевые слова: ВИЧ-СПИД, аденоассочиированный вирус, антисмысловые РНК, генная терапия, гемопоетические клетки человека.

\section{REFERENCES}

1. Baltimore D. Intracellular immunization // Nature.-1988.-335, N 6189.-P. 395-396.
2. Colman A. Antisense strategies in cell and developmental biology // J. Cell Sci.-1990.-97, Pt 3.-P. 399-409.

3. Yu M., Poeschla E., Wong-Staal F. Progress toward gene therapy for HIV infection // Gene Ther.-1994.-1, N 1.-P. 13-26.

4. Shved A. D. Polymicleothle inhibitors of virus reproduction (alkylated nucleic acids, iintiseiisc RNAs and ribozyme) // Biopolym. Cell.-1998.-14, N 4.-P. 332-342

5. Mosca J. D., Ritchey D. W, d'Arcy L. A., Burke D. S., The Henry M. Jackson. Expression of anti-HIV compounds directed from the HIV-LTR: a potential gene therapy for HIV infected individuals $/ / 6^{\text {th }}$ Int. AIDS Conf.-San Francisco, 1990.-P. 107.

6. Muzyczka N. Use of adeno-associated virus as a general transduction vector for mammalian cells // Curr. Top. Microbiol. Immunol.-1992.-158.-P. 97-129.

7. Nahreini P., Woody M. J., Zhou S. Z., Srivastava A. Versatile adeno-associated virus 2-based vectors for constructing recombinant virions // Gene.-1993.-124, N 2.-P. 257-262.

8. Sczakiel G., Oelze I., Rittner K. Microinjection: a technique to study inhibition of HIV-1 replication mediated by antisense RNA and parvovirus genes // Biotechnology applications of microinjection, microscopic imaging, and fluorescence / Eds P. H. Bach et al.-New York: Plenum Press, 1993.-P. 1-10.

9. Antoni B. A., Rabson A. B., Miller I. L., Trempe J. P., Chejanovsky N., Carter B. J. Adeno-associated virus Rep protein inhibits human immunodeficiency virus type 1 production in human cells // J. Virol.-1991.-65, N 1.-P. 396-404.

10. Sczakiel G., Oppenlander M., Rittner K., Pawlita M. Tat- and Revdirected antisense RNA expression inhibits and abolishes replication of human immunodeficiency virus type 1: a temporal analysis // J. Virol.-1992.-66, N 9.-P. 5576-5581.

11. Rittner K., Heilbronn R., Kleinschmidt J. A., Sczakiel G. Adeno-associated virus type 2-mediated inhibition of human immunodeficiency virus type 1 (HIV-1) replication: involvement of $\mathrm{p} 78 \mathrm{rep} /$ p68rep and the HIV-1 long terminal repeat // J. Gen. Virol.1992.-73, Pt 11.-P. 2977-2981.

12. Sullenger B. A., Gallardo H. F., Ungers G. E., Gilboa E. Overexpression of TAR sequences renders cells resistant to human immunodeficiency virus replication // Cell.-1990.-63, N 3.P. 601-608.

13. Graham G. J., Maio J. J. RNA transcripts of the human immunodeficiency virus transactivation response element can inhibit action of the viral transactivator // Proc. Natl Acad. Sci. USA.1990.-87, N 15.-P. 5817-5821.

14. Ivanskaya N. V., Lukash L. L., Shved A. D., Rybalko S. L., Sukhorada O. M., Zherebtsova E. M., Ruban T. O., Podolskaya S. V., Kukcharenko O. P., Grytsak T. F., Maksimenok O. V. Permissivness of human embryo liver cells for HIV infection // Biopolym. Cell.-1997.-13, N 3.-P. 245-249

Received 02.04.13 